\title{
The Development of the Digital Addiction Scale for the University Students: Reliability and Validity Study
}

\author{
Ahmet Kesici ${ }^{1, *}$ Nazenin Fidan Tunç ${ }^{2}$ \\ ${ }^{1}$ National Education Directorate, Siirt, Turkey \\ ${ }^{2}$ National Education Directorate, Diyarbakır, Turkey
}

Copyright $\odot 2018$ by authors, all rights reserved. Authors agree that this article remains permanently open access under the terms of the Creative Commons Attribution License 4.0 International License

\begin{abstract}
This study was carried out to develop a scale for determining the level of digital addiction of the youth. In this study carried out with a group of 687 students from Siirt, Dicle and Erzincan Universities, a draft scale of 28 items based on the interviews with two students who spent a long time with digital tools and their friends, and on the expert opinions was prepared. The validity of the Digital Addiction Scale (DAS) was determined by descriptive, confirmatory factor analysis, and criterion reliability. Item analysis based on the average of points of $27 \%$ lower-upper groups and item-total correlation was conducted. Reliability was determined by Cronbach's alpha and test-retest methods. The result of the factor analysis showed that the DAS explains the $59.51 \%$ of the total variance and has a structure consisting of five sub-dimensions called Overuse, Non-restraint, Inhibiting the Flow of Life, Emotional State, and Dependence. The confirmatory factor analysis showed that the DAS has good adaptive values. The scales applied concurrently with the DAS within the scope of criterion validity were also found to be in a significant and positive relation to the DAS. The item-total score correlation coefficients were found between .373 and 620 . The t- values of item mean scores of $27 \%$ lower-upper groups were found to be significant. Cronbach's Alpha was calculated 0.874 . The test-retest reliability made in a three-week interval was calculated $\mathrm{r}=.779 \quad(\mathrm{p}<.001)$. According to the findings of the study, it is possible to say that the DAS is a valid and reliable measurement tool that can be used to measure the digital addiction of the university students.
\end{abstract}

Keywords Addiction, Digital Addiction, Technology Addiction, Behavioral Addiction

\section{Introduction}

The developments in the information technologies have led to the production of such digital devices as mobile phone, desktop computer, laptop computer, smart TV, and tablet, and to marketing them with a cheap price. As a result of this, these digital devices have started to be used commonly at home and work [1]. Digital devices save time by easing human life, make quick access to information possible, and help to enjoy time. However, not using these devices in accordance with the needs and proportionately may lead to addiction especially among children and the youth [2].

Addiction is defined as impulse dependent on a habit of a certain activity or substance use though it has destructive effects on the physical, social, emotional, and mental health of the individual as well as his/her financial situation [3]. Addiction is classified in two ways. These are drug addiction and behavioral addiction. The mental, behavioral, and psychological problems observed in the individual depending on the use of such substances as alcohol and drugs are defined as drug addiction. The addiction in which the pathological problems (TV, gambling, game, and the Internet) seen in drug addiction without being dependent on any substance are observed is defined as behavioral addiction $[4,5,6]$.

There are six criteria to consider a behavior as an addiction. These are [7];

- Salience: That a certain action becomes vital in terms of life.

- Mood modification: That this action affects a person's mood.

- Tolerance: The increase in the amount of the action to show the same effect on the person.

- Withdrawal: That unpleasant emotions or physical symptoms are seen when the action does not continue or stops immediately.

- Conflict: The conflict that a person experiences as a result of the dilemma between him/her and the people around him/her.

- Relapse: That a certain action tends to occur again after the avoidance or control lasting long years. 
The developments in the digital software cause the new types of behavioral addiction to arise. Digital game addiction and Facebook addiction are the examples of the new types $[8,9]$ Therefore, that the individuals overuse the digital applications can be said to make them become addicted to the digital devices. In addition, new devices compatible with digital technology are developed, and new types of addictions enter the literature. Smart phone addiction is an example of this [10]. The fast developments in technology show that new types of addiction may be added to the types of addiction in this scope. Within this scope, digital addiction is a concept including such addictions as social networking addictions, smart phone addiction, Internet addiction etc. It seems that several studies on this issue have been made recently abroad [11, 12].

The studies on this issue should be made in order to protect the youth from the negative effect of behavioral addictions and to assist the ones who have such an addiction problem. There is a need to conduct such studies in our country because digital addiction is also a serious problem for the youth in our country. The opening of the polyclinics serving only for the youth with digital addiction is the biggest proof of this [13]. It is very important to determine behavioral addiction depending on technological developments based on the Internet and to use the scales measured to be reliable and valid in the studies related to this issue. There are several scales developed to measure the types of addiction considered to be a type of digital addiction and translated into Turkish in the literature. The Problematic Internet Use Scale by Ceyhan, Ceyhan, and Gürcan (2007) [14], the Internet Addiction Scale developed by Nichols and Nicki (2004) and adapted to Turkish by Kayri and Günüç (2009) [15], and the Online Cognition Scale developed by Davis and translated into Turkish by Özcan and Buzlu (2005) [16] are examples of such scales. In addition, the Facebook Addiction Scale developed by Andreassen, Torsheim, Brunborg, and Pallesen (2012) and adapted to Turkish by Türkyılmaz (2015) [17], the Facebook Addiction Scale by Çam (2012) [9], the Digital Game Addiction Scale of Lemmens and his colleagues (2009) translated into Turkish by Irmak and Erdoğan [8], Kwon and her colleagues' (2013) the Smart Phone Addiction Scale adapted to Turkish by Demirci, Orhan, Demirdas, Akpinar, and Sert (2014) [18], and Bianchi and Phillips' (2005) the Problematic Mobile Phone Use Scale translated to Turkish by Şar and Işıklar (2012) [19] can be considered within the scope of digital addiction in terms of software and applications developed based on the Internet, and the tools making access to the Internet possible.

The Internet is a network connecting all of the computers on the world to each other. In fact, since the Internet is a way enabling to share information [20], the software and applications developed based on the Internet and the tools made for using these software and applications may lead to the Internet addiction. That is, digital software and applications make the individual addicted to digital tools.
Because of this, different digital tool and software addictions can be mentioned instead of the Internet addiction. Within this scope, the scales mentioned above can be said to be useful in measuring the different types of digital addiction. Therefore, the measurement tools being capable of covering all of such addictions as the Internet, computer, smart phone, game, and Facebook and of behavioral addictions which digital software applications and devices possibly entering our lives in the future will cause should be developed. This study aims to develop a scale which will be able to measure the digital addiction of the university students in line with this purpose. Aslan, Kırık, Karaman, and Çetinkaya (2015) [2] developed a digital addiction scale for Turkish university students, but this scale focuses only on game and social network use. With the scale aimed to be developed in this study, it can be possible to measure the addiction resulting from the use of digital tools for communication, game, shopping, watching a film etc. with a single scale. It can also be possible to compare the addiction levels of digital tools used for different purposes with one another and to determine which purpose for using digital tools is more effective in the development of addiction to digital tools.

\section{Method}

A systematic approach processing gradually was followed in the development of the DAS.

\subsection{Study Group}

The DAS was developed with three different student groups. The construct validity, item analysis, and internal consistency study of the scale were made with 196 students (95 females and 74 males) from Siirt University, 157 students ( 99 females and 58 males) from Dicle University, and 201 students (140 females and 61 males) from Erzincan University, totally 527 students in faculty of education in the 2015-2016 education year. The test-retest reliability of the scale was investigated with 78 students in faculty of veterinary sciences at Siirt University in the 2016-2017 education year. The criterion validity of the scale based on the smart phone, digital game, and the Internet addictions was studied with the same student group. In addition, the criterion validity of the scale based on the Facebook addiction was searched with another student group consisting of 82 students in faculty of veterinary sciences at Siirt University in the same education year.

\subsection{Preparing the Draft Scale}

The literature was firstly reviewed in the process of developing the draft scale. Then, two students from the Faculty of Education of Siirt University who spent time with the digital devices intensively were determined with the support of the academicians working at the Faculty of 
Education. The determined students were contacted, informed about the study, and asked for help. They accepted to participate in the study. Two interviews were made with them separately. A friend of each student was asked to accompany them in the interviews. Therefore, their friends' observations on them were benefitted. Within the scope of the criteria which Griffiths (1999) [7] explained for behavioral addiction, a computer and instructional technologies teacher and a counsellor joined both interviews with the researcher. In accordance with the interviews made, a draft scale consisting of 28 items which covered each of the criteria Griffiths (1999) [7] explained for behavioral addiction was prepared. The opinions of one psychologist and psychiatrist about the relevance of the items in the draft were taken. Both experts mentioned that the questions were fit for the purpose of this study.

\subsection{Data Collection Tools}

\subsubsection{The Digital Game Addiction Scale (DGAS)}

The digital game addiction of the university students was determined with the Digital Game Addiction Scale (DGAS) developed Lemmens et al. and adapted to Turkish by Irmak and Erdoğan. The DGAS consists of 7 items and is a five-point Likert-type scale. The Cronbach's alpha coefficient of the scale adapted with 95 teenagers to Turkish was calculated 0.72 . The scale composed of one dimension explains the $56.96 \%$ of the total variance [8]

\subsubsection{The Facebook Addiction Scale (FAS)}

The Facebook addiction of the university students was determined with the FAS which Çam developed by adapting the Internet Addiction Test developed by Young to the Facebook addiction. The adaptation of the Internet Addiction Test to the Facebook Addiction Scale was made with 1494 university students. The FAS consists of one dimension, and its Cronbach's alpha coefficient is 0.93 . It explains the $43.86 \%$ of the total variance. It has 19 items and is a six-point Likert-type scale [9].

\subsubsection{The Smart Phone Addiction Scale - Short Form (SPAS-SF)}

The smart phone addiction of the university students was found out with the short form of the Smart Phone Addiction Scale which Noyan et al. adapted to Turkish from the long form of the Smart Phone Addiction Scale with 33 items developed by Kwon et al. The SPAS-SF consisting of 10 items is a six-point Likert-type scale. The Cronbach's alpha coefficient of the scale whose Turkish adaptation study was made with 367 students was measured 0.867. It was determined that the SPAS-SF having a one-dimensional structure explains the $46.3 \%$ of the total variance [10].

\subsubsection{The Young's Internet Addiction Test Short Form (YIATSF)}

The Internet addiction of the youth was revealed by using the Internet Addiction Test - Short Form developed by Young and adapted to Turkish by Savc1 et al. The YIATSF is a one-dimensional, 12-item, and five-point Likert-type scale. Its Cronbach's alpha coefficient was calculated 0.91 , and it was determined to explain the $39.52 \%$ of the total variance in the Turkish adaptation study made with the university students [21].

\subsection{Data Collection and Analysis}

Permission was taken from the faculty members who worked at the universities where the students in the research group studied. The data were collected by the faculty members within their class times. The data collected based on voluntariness were computerized and analyzed with SPSS and LISREL.

\section{Findings}

\subsection{Exploratory Factor Analysis}

Before making the factor analysis, the item-total point correlation coefficients of each item was calculated. If the item-total point correlation is below 0.30 , it means that the discrimination levels of the items are good [22]. Therefore, the $15^{\text {th }}$ and $18^{\text {th }}$ items whose item-total correlation points are below 0.30 were not included in the factor analysis.

The number of 500 participants is good for the sample size in the factor analysis [23]. Therefore, the sample size in this study is sufficient. The fitness of the data for the factor analysis was determined with Kaiser-Meyer-Olkin (KMO) test and Bartlett Test of Sphericity. That the KMO value is above .80 indicates that the fitness of the variables for the factor analysis is in the "perfect" level. That the result of the Bartlett Test of Sphericity is significant shows that there is a sufficient relation among the variables to make the factor analysis [24]. The varimax approach was adopted as to develop a scale which will obtain the highest amount of information with a few items by decreasing the number of variables was aimed. Eigenvalue is an important variable in deciding the number of factors in the factor analysis. The factors, whose eigenvalues are 1 and above 1 , are considered as significant factors. The items in which there is a difference less than 0.10 between their factor loadings in two factors are called as common items in the exploratory factor analysis. It is suggested that common items be extracted from the scale [22]. As a result of the factor analysis, it was seen that there is a structure consisting of five sub-dimensions and explaining the $55.075 \%$ of the variance $($ Bartlett test $=5054.075(\mathrm{p}<.01)$; $\mathrm{KMO}=.922)$. Yet, the factor analysis was repeated by extracting 6 items (items 4-20-2-2-26-22) as they were common items. Accordingly, it was observed that there is a structure composed of five sub-dimensions and explaining the $57.723 \%$ of the variance (Bartlett test $=3692.483$ $(\mathrm{p}<.01) ; \mathrm{KMO}=.901)$. Yet, as the $13^{\text {th }}$ item did not have the relevant factor loading, it was extracted, and the factor 
analysis made again. According to the renewed factor analysis, it was found out that there is a structure with 5 sub-dimensions which explains the $58.875 \%$ of the variance $($ Bartlett test $=3492.027(\mathrm{p}<.01) ; \mathrm{KMO}=.899)$. Similarly, as it was seen that the $7^{\text {th }}$ item did not have the relevant factor loading, it was extracted, and the factor analysis was made third time. It was revealed that the DAS explains the $59.510 \%$ of the total variance and has a five-dimensional structure in the last factor analysis $($ Bartlett test $=3203.754(\mathrm{p}<.01) ; \mathrm{KMO}=.899)$. The factor loadings of each item remaining in the scale are above 0.45 . The value is 0.45 or above 0.45 is considered as a good criterion [25]. The five items gathered in the first factor called as Overuse. It explains the $13.522 \%$ of the variance. The second factor consisting of 3 items and called as Non-restraint explains the $12,273 \%$ of the variance. The third factor composed of 4 items explains the $11.840 \%$ of the variance. It was named as Inhibiting the Flow of Life. The forth factor called as Emotional State consists of 4 items and explains the $11.361 \%$ of the variance. The fifth dimension composed of 3 items and explaining the $10.512 \%$ of the variance was called as Dependence. The findings obtained as a result of the exploratory factor analysis were shown in Table 1.

\subsection{Confirmatory Factor Analysis (CFA)}

Confirmatory Factor Analysis (CFA) was made in order to test whether the DAS would be confirmed as a model or not. CFA made with LISREL is an advanced technique used to test the theories related to the latent variables [26]. The structural model in Figure 1 was tested with LISREL. In Figure 1, the standardized path coefficients showing the item-factor relation are above the arrows drown from the latent variable (the sub-dimensions in this study) to the measurement variables (the scale items in this study). All of the path coefficients were seen to be statistically significant. This means that the items made significant contributions to the the sub-dimensions they belong to.

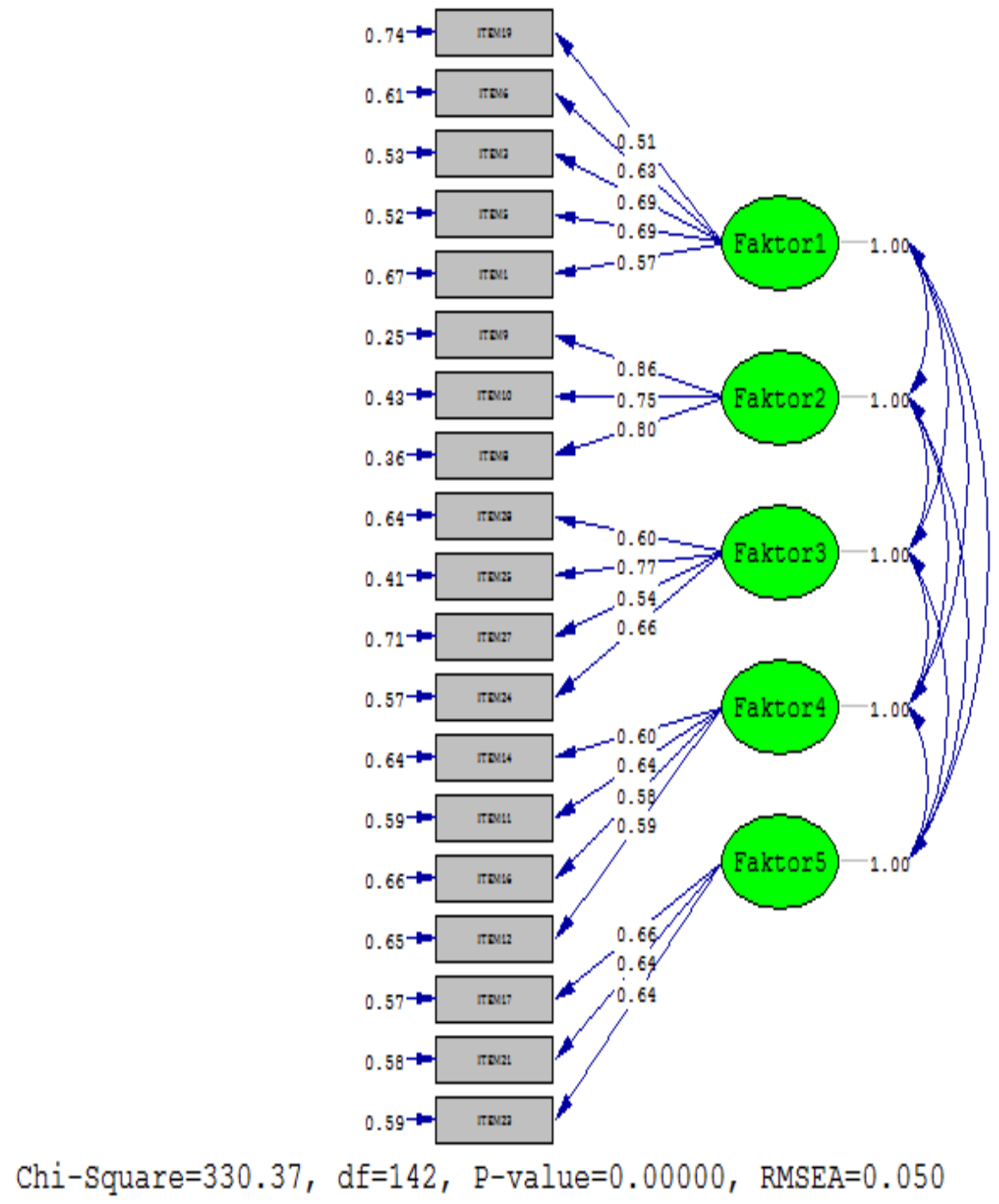

Figure 1. The results of confirmatory factor analysis 
The fit indices obtained as a result of CFA give information about whether the data confirm the factor structure of the scale or not. According to this, it was obtained as $\chi^{2} / \mathrm{sd} 2.326$. As this value is below 3, the goodness of fit can be considered as perfect. The value of RMSEA, one of the fit indices, was calculated 0.05 . That the RMSEA is 0.080 and below it shows the good level and that it is 0.05 and below 0.05 indicates the perfect fit. In addition, NFI, CFI, IFI, and RMR among the most commonly used fit indices were found $0.90,0.94,0.94$, and 0.058 respectively. These findings are in the acceptable level [22, 23]. The findings obtained as a result of confirmatory factor analysis were shown in Table 1.

\subsection{Reliability}

The Cronbach's alpha reliability coefficient of the DAS was measured 0.874 . The Cronbach's alpha reliability coefficients of the first, second, third, fourth, and fifth sub-dimensions of the DAS were calculated $0.753,0.845$, $0.739,0.695$, and 0.695 in order. That the Cronbach's alpha coefficient is between 0.60 and 0.90 is considered that the scale is considerately reliable [27].

The DAS was divided into two halves as the odd- and even-numbered items [28]. The reliability of one of the semi-scales formed with this method was calculated.95, and the Spearman-Brown reliability coefficient of the whole scale was measured .97. The Pearson correlation coefficient of the averages of the points taken from the scales which were formed by dividing the DAS as the odd and even numbers was found $.849(\mathrm{p}<0.01)$.

\subsection{Item Analyses}

The item-total point correlation of the items in the DAS was calculated. The lowest value obtained was .373, and the highest value was found .620 . The value higher than .30 means that the items' discrimination is good [22]. The total scale point was measured in order to make item analyses based on the averages of lower-upper groups, and the highest $27 \%$ and the lowest $27 \%$ were named as upper group and lower group in the order of the observation. Whether the differences in the item points belonging to the lower and upper groups were statistically significant or not was measured with independent sample t-test. According to this, it was determined that all of the $\mathrm{t}$ values were significant ( $\mathrm{sd} .=282$; for every item $\mathrm{p}<.01$ ). Therefore, it is understood that each item in the scale makes a consistent classification [28]. The findings of the item analyses were presented in Table 1.

Table 1. The results obtained as a result of the factor analysis and item analyses

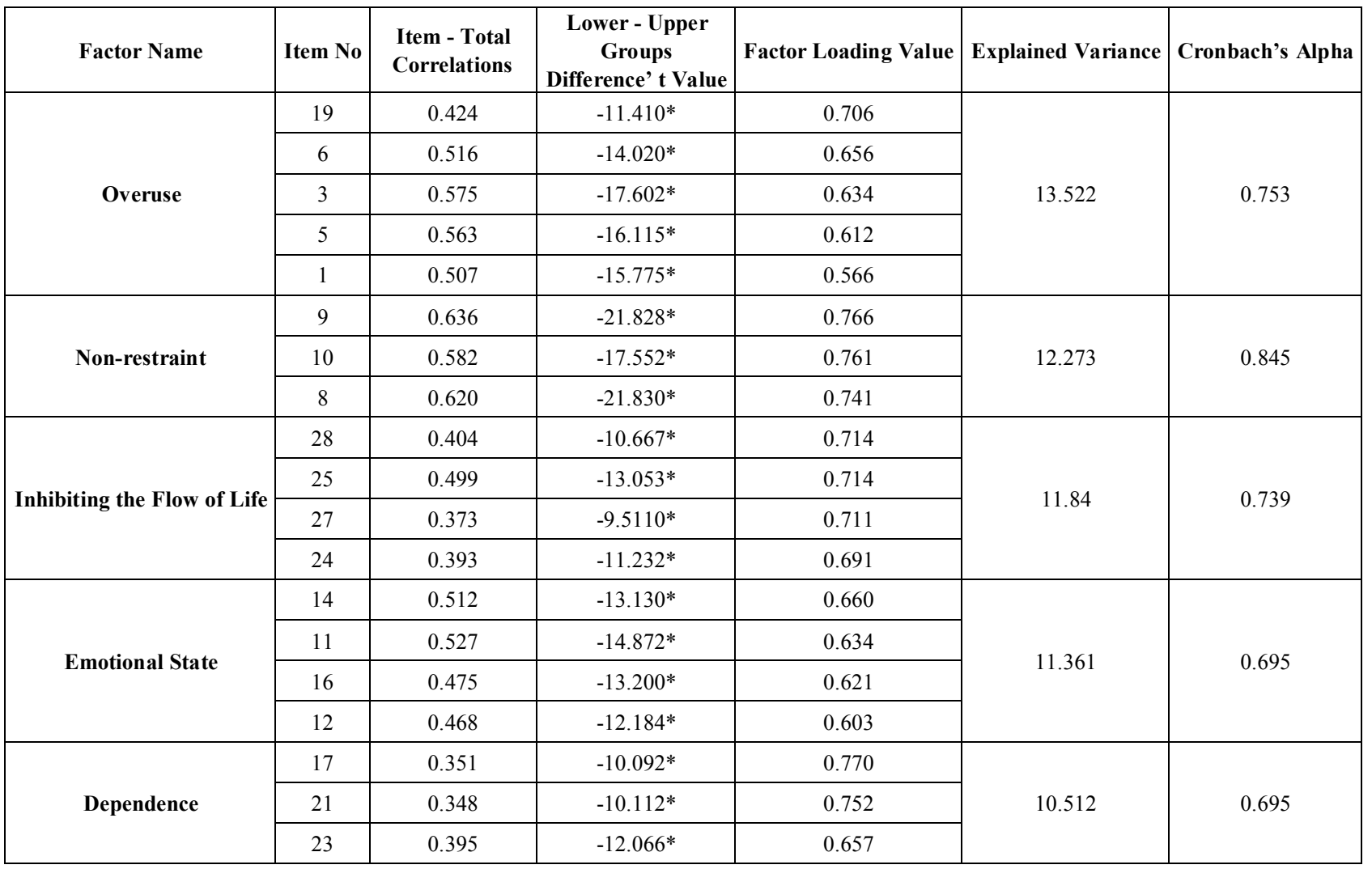




\subsection{Test-Retest Reliability}

The DAS was applied to 64 students in a three-week interval. The Pearson correlation coefficient between the averages obtained in both applications was calculated. Accordingly, a positive correlation between the points at the 0.001 level was found $(r=.779 ; \mathrm{p}<0.001)$.

\subsection{Criterion Validity}

In order to determine the concurrent validity of the DAS, the DAS and YIATSF were concurrently applied to 82 students, the DAS and SPAS-SF to 78 students, and the DAS and FAS to 75 students. Pearson correlation test was made among the averages of the points obtained from the scales. The results were presented in Table 2 .

Table 2. The results of the correlation analyses made for criterion-based validity

\begin{tabular}{|c|c|c|c|}
\hline Addiction & Addiction & $\mathbf{n}$ & $\mathbf{r}$ \\
\hline $\begin{array}{c}\text { Digital Addiction } \\
\text { (DAS) }\end{array}$ & Internet Addiction (YIATSF) & 82 & $.756^{* *}$ \\
\hline $\begin{array}{c}\text { Digital Addiction } \\
\text { (DAS) }\end{array}$ & $\begin{array}{c}\text { Smart Phone Addiction } \\
\text { (SPAS-SF) }\end{array}$ & 78 & $.833^{* *}$ \\
\hline $\begin{array}{c}\text { Digital Addiction } \\
\text { (DAS) }\end{array}$ & Game Addiction (DGAS) & 78 & $.600^{* *}$ \\
\hline $\begin{array}{c}\text { Digital Addiction } \\
\text { (DAS) }\end{array}$ & Facebook Addiction (FAS) & 75 & $.447 *$ \\
\hline$* * p<001$
\end{tabular}

$* * \mathrm{p}<.001$

As seen in Table 2, a positive and significant relation at the 0.001 level was found between the averages of the points obtained from the DAS and other scales.

\subsection{Scoring the Scale}

After the scale is applied to the individual whose digital addiction level is to be measured, 5, 4, 3, 2, and 1 point are given to the options "Totally Agree", "Agree", "Neither Agree nor Disagree", "Disagree", and "Totally Disagree" in order. The points are summed up and are divided by the number of the items. Thus, the digital addiction levels of the students are measured. The expected point range is 1.00 (the lowest) and 5.00 (the highest), and high point relatively indicates that the digital addiction level of the individual is high.

\section{Discussion, Conclusion and Suggestions}

The DAS was developed to measure the digital addiction levels of the university students in this study. The DAS has a structure which consists of 19 items, is five-point Likert-type, and is composed of five sub-dimensions called Overuse, Non-restraint, Inhibiting the Flow of Life, Emotional State, and Dependence. The Cronbach's alpha reliability of the whole scale was calculated 0.874 , and it was determined that the scale explains the $59.51 \%$ of the variance. As a result of the confirmatory factor analysis, the $\chi^{2} /$ sd. was found 2.326, and the RMSEA value was calculated 0.05. In addition, the NFI, CFI, IFI, and RMR values were obtained as $0.90,0.94,0.94$, and 0.058 respectively. The test-retest reliability coefficient made in a three-week interval was $r=.779(p<.001)$. In order to determine the criterion-based validity of the DAS, the DAS was applied concurrently with the YIATSF, SPAS-SF, DGAS, and FAS, and the correlation coefficients between them were measured $.833, .756, .600$, and .447 (all of them are significant at the 0.001 level) successively. The results obtained demonstrate that the Digital Addiction Scale can be used to measure the digital addiction levels of the university students.

The DAS was determined to explain the $60 \%$ of the variance. This ratio can be said to be very good when compared to the scales which are used in several studies in Turkey and are related to digital addiction. For example, the explanatoriness of the Problematic Internet Use Scale by Ceyhan, Ceyhan, and Gürcan (2007) [14] is 49\%, and the explanatoriness of the Internet Addiction Scale adapted to Turkish by Kayri and Günüç (2009) [15] is 33\%, both of which measure general addiction like the DAS. The explanatoriness of the Facebook Addiction Scale translated into Turkish by Türkyılmaz (2015) [17] is 74\%, the one of the Smart Phone Addiction Scale adapted to Turkish by Demirci and his colleagues (2014) [18] is nearly 66\%, and the one of the Digital Game Addiction Scale which Irmak and Erdoğan adapted to Turkish is almost $57 \%$, all of which measure more specific types of addiction. Therefore, the DAS can be used in the studies related to technology-based behavioral addiction reliably.

This study is limited as it was conducted with the students studying at Siirt, Dicle, and Erzincan Universities. That its validity and reliability study will be made with the students studying at different faculties and at different universities can be beneficial. The studies which will be made for the reliability and validity of the DAS for the teenagers can provide great contributions to the field. Finally, there may be said to be a need to make new studies for the criterion validity of the DAS. 


\section{Appendix: The Digital Addiction Scale}

\begin{tabular}{|c|c|c|c|c|c|c|c|}
\hline & & Dijital Bağımlılık Ölçeği & & & & & \\
\hline & & The Digital Addiction Scale & & & & & \\
\hline 娄 & & $\begin{array}{l}\text { Așağıdaki her bir maddeyi okuyun bu madde sizin için her zaman doğru ise Tamamen Katılyorum genelde doğru ise } \\
\text { Katılyorum, emin değilseniz Kararsızım, genelde doğru değilse Katılmıorum, hiçbir zaman doğru değilse Kesinlikle } \\
\text { Katılmyorum șeklinde ișaretleyiniz. } \\
\text { Read each item below. If the item is always true for you, mark Totally Agree, if general true for you, mark Agree, if you are not } \\
\text { sure, mark Neither Agree nor Disagree, if it is not generally true for you, mark Disagree, and if never true for you, mark Totally } \\
\text { Disagree. }\end{array}$ & 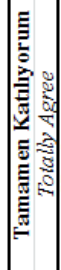 & 恼 & 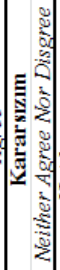 & 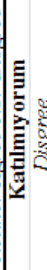 & 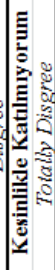 \\
\hline & & Yemek yerken aynı zamanda telefon, tablet ya da bilgisayarımla meșgul olurum. & & & & & \\
\hline & 19 & While eating my meal, I am occupied with mobile phone, tablet, or computer. & & & & & \\
\hline & & Gezi, piknik veya arkadașlarla olduğum sosyal ortamlarda sürekli dijital araçlarına (cep telefonu ya da tablet) bakarım. & & & & & \\
\hline E & 0 & I continously look at the digital devices (mobie phone or tablet) in a trip, picnic or social environments where I am with my friend. & & & & & \\
\hline 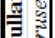 & (2) & Dijital araçları amacı dıșında așırı bir șekilde kullanıyorum. & & & & & \\
\hline 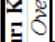 & 3 & I overuse the digital devices out of their purposes. & & & & & \\
\hline 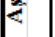 & & Bir ișle uğrașırken kendimi dijital araçlarımı kontrol ederken buluyorum. & & & & & \\
\hline & 3 & I find myself checking my digital devices upon dealing with a work. & & & & & \\
\hline & & Dikkat gerektiren ișleri yaparken bile telefon, tablet gibi dijital araçlarla uğrașırım. & & & & & \\
\hline & 1 & I deal with the digital devices like table even if I do demanding things & & & & & \\
\hline & & Dijital araçları kullanma süresini konusunda kendimi kontrol edemiyorum. & & & & & \\
\hline$\approx$ & 9 & I can not control myself on the amount of time of using the digital devices. & & & & & \\
\hline 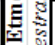 & 10 & Dijital araçlarla harcadığım zamanı kısmak için bașarısız çabalarım oldu. & & & & & \\
\hline 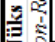 & 10 & I have unsuccessful attemps to reduce the time I spend with the digital devices. & & & & & \\
\hline & & Dijital araçlarla harcadığım zamanı azaltamıyorum. & & & & & \\
\hline & 0 & I can not reduce the time I spend with the digital devices. & & & & & \\
\hline & & Dijital araçlar ev ve okul ile ilgili sorumluluklarımı yerine getirmemi engelliyor. & & & & & \\
\hline$\stackrel{\leftrightarrow}{\Xi}$ & 28 & The digital devices prevent me from doing my responsibilities related to home and school. & & & & & \\
\hline 可 & $0=$ & Dijital araçlarla çok vakit harcadığımdan dolayı birçok fırsatı kaçırdığım olmuștur. & & & & & \\
\hline 車事 & 25 & I have missed many opportunities because of spending a lot of time with the digital devices & & & & & \\
\hline$\frac{1}{2}$ & 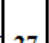 & Dijital araçlarla uğraștığım zaman çevremde olup bitenden haberim olmaz. & & & & & \\
\hline$E:$ & 27 & I am unaware of what happens around me when I deal with the digital devices. & & & & & \\
\hline 瑅: & 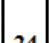 & Dijital araçları kullanmam nedeniyle üretkenliğimin azaldığııı hissediyorum. & & & & & \\
\hline & 24 & I feel that I become less creative because of using the digital devices. & & & & & \\
\hline & 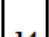 & Dijital araçlarla vakit geçirirken bana herhangi bir iș verilmesi beni öfkelendirir. & & & & & \\
\hline & 14 & Assigning a job to me when I spend time with digital devices makes me annoye digital devicesd. & & & & & \\
\hline 吾 & 1 & Dijital araçları kullanamayacağım ortamlar beni sıkar. & & & & & \\
\hline 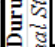 & II & The environments where I can not use the digital devices bore me. & & & & & \\
\hline$E_{0}:$ & . & Sahip olduğum dijital araçları uzun süre kullanmadığımda kendimi çok mutsuz ve sinirli hissederim. & & & & & \\
\hline 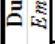 & 10 & I feel very unhappy and angry when I do not use my digital devices for a long time. & & & & & \\
\hline & 13 & Dijital araçlarla vakit geçirirken kendimi çok mutlu hissediyorum & & & & & \\
\hline & 12 & I feel very happy I spend time with the digital devices. & & & & & \\
\hline & & Sahip olduğum dijital araçların bozulması veya kaybolması beni huzursuz eder. & & & & & \\
\hline & 17 & That my digital devices are broken or get lost makes me anxious. & & & & & \\
\hline 章 & & Kısa süreliğine bile olsa evden ayrıldığımda telefon/tablet gibi dijital araçları yanıma almak isterim. & & & & & \\
\hline$\frac{\pi}{3}$ & 21 & Even if I leave my house for a short time, I want to take the digital devices like phone/tablet with me. & & & & & \\
\hline & 2 & Akıllı telefon ve tablet gibi dijital araçları yatarken yakınımda bulunduruyorum. & & & & & \\
\hline & 23 & I keep digital devices like smart phone or tablet around when I go to sleep. & & & & & \\
\hline
\end{tabular}




\section{REFERENCES}

[1] Temel, F., Önürmen, O., \& Köprü, M. (2014). Digital means and the internet during electoral campaigns: a case study on university students. Global Media Journal: Turkish Edition, 5(9), 322-337.

[2] Arslan, A., Kırık, A. M., Karaman, M., \& Çetinkaya, A. (2015). Digital addiction in high school and university students. International Peer-Reviewed Journal of Communication and Humanities Research, 8(8), 34-58.

[3] Young, K. S., Yue, X. D., \& Ying, L. (2011). Prevalence estimates and etiologic models of Internet addiction. Internet addiction: A handbook and guide to evaluation and treatment, 3-17.

[4] Kır, İ., \& Sulak, Ş. (2014). Determining internet addiction level of faculty of education students. Electronic Journal of Social Sciences, 13(51), 150-167.

[5] Gününç, S., \& Kayri, M. (2010). The profile of internet dependency in Turkey and development of internet addiction scale: Study of validity \& reliability. Hacettepe University Journal of Education, 39(39): 220-232.

[6] You, S., Kim, E., \& Lee, D. (2017). Virtually real: exploring avatar identification in game addiction among massively multiplayer online role-playing games (MMORPG) players. Games and Culture, 12(1), 56-71.

[7] Griffiths, M. (1999). Internet addiction: Fact or fiction? The Psychologist, 12(5), 246-250. (Trans.: K. Alat), Turkish Psychological Bulletin 1999. ISSN: 1300-7408. Available from:

http://www.isgucdergi.org/?p=article \&id=39\&cilt=5\&sayi $=$ 1\&yil=2003. Available on September 15, 2016.

[8] Yalçın Irmak, A., \& Erdoğan, S. (2015). Validity and reliability of the Turkish version of the Digital Game Addiction Scale. Anatolian Journal of Psychiatry. Anatolian Journal of Psychiatry, 16 (Special issue 1), 10-18.

[9] Çam, E. (2012). Çam E. Educational and general use of facebook and facebook addiction of teacher candidates (SAU College of Education Sample) (Unpublished Master's Thesis), University of Sakarya: Sakarya, 2012.

[10] Noyan, C. O., Enez Darçın, A., Nurmedov, S., Yılmaz, O., \& Dilbaz, N. (2015). Validity and reliability of the Turkish version of the Smartphone Addiction Scale-Short Version among university students. Anatolian Journal of Psychiatry 2015; 16(Special issue 1), 73-81.

[11] Jiang, J., Phalp, K. T., \& Ali, R. (2015). Digital addiction: Gamification for precautionary and recovery requirements. Retrieved from:

http://eprints.bournemouth.ac.uk/21887/1/04-Posters.pdf

[12] Cover, R. (2004). Digital addiction: The cultural production of online and video game junkies. Media International Australia incorporating Culture and Policy, 113(1), 110-123.
[13] URL (2016)

http://sosyalmedya.co/bakirkoy-internet-bagimliligi-polikli nigi/ Available on January 31.01.2016.

[14] Ceyhan, E., Ceyhan A. A. ve Gürcan, A. (2007). The validity and reliability of the problematic internet usage scale. Educational Sciences: Theory \& Practice, 7(1), 411-416.

[15] Kayri, M., \& Günüç, S. (2009). The adaptation of internet addiction scale into Turkısh: The study of validity and reliability. Ankara University, Journal of Faculty of Educational Sciences, 42(1), 157-175. DOI: 10.1501/Egifak_0000001142 Yayın Tarihi: 2009

[16] Özcan, N. K., \& Buzlu, S. (2005). An Assistive Tool in Determining Problematic Internet Use: Validity and Reliability of the "Online Cognition Scale" in a Sample of University Students. Journal of Dependence, (6), 19-26.

[17] Türky1lmaz, M. (2015). The translation of Facebook addiction scale into Turkish and impact of Facebook addiction to reading ability. The Journal of Academic Social Science Studies, 36, 265-280. Doi number:http://dx.doi.org/10.9761/JASSS2942

[18] Demirci, K., Orhan, H., Demirdas, A., Akpinar, A., \& Sert, H. (2014). Validity and reliability of the Turkish Version of the Smartphone Addiction Scale in a younger population. Klinik Psikofarmakoloji Bülteni-Bulletin of Clinical Psychopharmacology, 24(3), 226-234.

[19] Şar, A. H., \& Işıklar, A. (2012). Adaptation of problem mobile phone use scale to Turkish. Journal of Human Sciences, 9(2), 264-275.

[20] Atav, E., Akkoyunlu, B., \& Sağlam, N. (2006). Prospective teachers' internet access facilities and their internet usage. Hacettepe University Journal of Education, 30(30), 37-44.

[21] Kutlu, M., Savc1, M., Demi, Y., \& Aysan, F. (2016). Turkish adaptation of Young's Internet Addiction Test-Short Form: a reliability and validity study on university students and adolescents. Anatolian Journal of Psychiatry, 17(Special issue 1), 69-76. doi: 10.5455/apd.190501

[22] Büyüköztürk, Ş. (2011). Sosyal bilimler için veri analizi el kitabl (15. Bask1). Ankara, Pegem Akademi.

[23] Çokluk, O., Şekercioglu, G., \& Büyüköztürk, Ş. (2012) Sosyal bilimler için çok değişkenli SPSS ve LISREL uygulamalari. Ankara: Pegem Akademi Yayıncılı.

[24] Durmuş, B., Yurtkoru, E. S., \& Çinko, M. (2011). Sosyal bilimlerde SPSS'le veri analizi. İstanbul: Beta Basım Yayım.

[25] Bayram, N. (2012.) Sosyal bilimlerde SPSS ile veri analizi (3. Bask1). Bursa: Ezgi.

[26] Tabachnick, B. G., \& Fidell, L. S. (2007). Using multivariate statistics (5th Edn.). Boston: Pearson Education.

[27] Can, A. (2014). SPSS ile bilimsel araştırma sürecinde nicel veri analizi (3. Bask1). Ankara: Pegem Akademi.

[28] Tekin H. (2012). Ĕ̌itimde ölçeme ve değerlendirme (21. Bask1). Ankara: Yarg1 Yayınları. 